RESEARCH NOTE

\section{Effects of Euphorbia milii Latex on Schistosoma mansoni Eggs, Miracidia and Cercariae}

\section{RR De-Carvalho, A Maldonado Jr*/+, EC Oliveira-Filho/ ${ }^{++}$, AC Ribeiro*, FJR Paumgartten, L Rey*}

\author{
Laboratório de Toxicologia Ambiental, Escola \\ Nacional de Saúde Pública, Fiocruz *Laboratório de \\ Biologia e Controle da Esquistossomose, \\ Departamento de Medicina Tropical, Instituto \\ Oswaldo Cruz, Av. Brasil 4365, 21045-900 Rio de \\ Janeiro, RJ, Brasil \\ Key words: niclosamide - plant molluscicides - \\ Euphorbiaceae - schistosomiasis - Euphorbia \\ splendens
}

The latex of "Crown-of-Thorns" (Euphorbia milii var hislopii) is a potent plant molluscicide and a promising alternative to niclosamide (NCL), today`s mostly used molluscicidal compound (MC Vasconcellos \& VT Schall 1986 Mem Inst Oswaldo Cruz 81: 475-476). In addition to being an effective molluscicide, NCL also kills miracidia and cercariae, the two free living stages of Schistosoma trematodes. It is active against other helminths as well. Owing to its prominent cestocide activity NCL has been used in human and veterinary medicine as a drug of choice to treat several tapeworm infections (P Andrews et al. 1983 Pharmac Ther 19: 245-295). However, the effects of E. milii on helminths have not been studied so far. In this study we investigated the effects of E. milii latex on S. mansoni eggs, miracidia and cercariae. Data on the toxicity of NCL to these developmental stages of $S$. mansoni were also obtained for comparative purposes.

E. milii latex was obtained from plants cultivated in the district of "Ilha do Governador", Rio de Janeiro, Brazil, in July-August, 1995. Lyo-

Research supported by Papes/Fiocruz and CNPq.

${ }^{+}$Corresponding author. Fax: +55-21-280.3740.

${ }^{++}$Recipient of a fellowship from Faperj.

Received 4 May 1998

Accepted 31 August 1998 philized latex and NCL ethanolamine salt (BayluscideWP70 ${ }^{\hat{a}}$ ) were dissolved in dechlorinated water. S. mansoni eggs, miracidia and cercariae were from the "Belo Horizonte" (BH) strain maintained in Biomphalaria glabrata snails and Swiss-Webster mice (WL Paraense \& L Corrêa 1989 Mem Inst Oswaldo Cruz 84: 281-288).

Eggs hatching inhibition test - Schistosoma eggs were recovered from infected Swiss mice. Livers were homogenized in $\mathrm{NaCl} 1.7 \%$ w/v. The homogenate was filtered and left to stand for $1 \mathrm{hr}$. The sediment containing eggs was resuspended in $\mathrm{NaCl} 1.7 \% \mathrm{w} / \mathrm{v}$ and again left to stand for $1 \mathrm{hr}$. The procedure was carried out in the dark at $4^{\circ} \mathrm{C}$. The eggs were then incubated in the dark at $26^{\circ} \mathrm{C}$ for $2 \mathrm{hr}$ in the presence of latex $(10,25,50$ and $100 \mathrm{mg} / \mathrm{l})$, NCL $(0.05,0.1$ and $10 \mathrm{mg} / \mathrm{l})$ or dechlorinated water. Solutions were placed under a tungsten lamp $(60 \mathrm{~W})$ during $1 \mathrm{hr}$ for egg hatching. Hatching was stopped by adding an alcohol-formalin-acetic acid solution. The proportions of hatched and unhatched eggs were scored in samples of 30 eggs.

Lethality to miracidia - The sediment containing eggs was resuspended in dechlorinated water and exposed to artificial light (60W). Owing to their phototaxic behaviour, swimming miracidia flocked to the illuminated side-arm of a $150 \mathrm{ml}$ glass flask where they were collected. thirty miracidia per concentration of latex or NCL were then exposed to testing solutions in multi-well plates. The number of living miracidia was recorded after 2, 3 and $4 \mathrm{hr}$ of exposure to testing solutions. All miracidia were tested within $2 \mathrm{hr}$ after hatching.

Lethality to cercariae - Freshly shed cercariae were exposed to testing solutions $(200 \pm 2$ cercariae per concentration) in tissue culture plates ( $60 \times 15$ $\mathrm{mm}$ ) for $4 \mathrm{hr}$. Evans Blue dye was used to stain dead cercariae. The numbers of living and dead cercariae were recorded. The experiment was repeated three times.

Effect on cercariae infectivity - Freshly shed cercariae were exposed to testing solutions for 2 $\mathrm{hr}$ in $5 \mathrm{ml}$ assay tubes. Female Swiss Webster mice (4 to 6 weeks-old) had their tails immersed in assay tubes containing 100 pretreated cercariae for $30 \mathrm{~min}$. Ten mice per concentration of latex or NCL were used. The number of cercariae that failed to penetrate the mouse skin was counted, and all infected mice were killed eight weeks later. Adult worms were recovered from mesenteric veins after a portal-hepatic perfusion.

The present study findings suggested that NCL $(0.05 \mathrm{mg} / \mathrm{l})$ does not interfere with $S$. mansoni eggs hatching. Approximately 50\% of eggs hatched during the $3 \mathrm{hr}$ test period in the control group as well as in NCL - and latex-treated groups. No dif- 
ference between control and treated groups was found. Contrasting with the lack of action on eggs, NCL $(0.05 \mathrm{mg} / \mathrm{l})$ proved to be lethal to swimming miracidia (Table I) and cercariae (Table II). No previous investigation of NCL effects on eggs was found in the literature, but its miracidicidal and cercaricidal properties have been observed by several authors. For instance, it was reported that $S$. mansoni miracidia were killed by NCL at concentrations as low as $0.3 \mathrm{mg} / \mathrm{l}$ (within minutes) and $0.1 \mathrm{mg} / \mathrm{l}$ (after longer exposures) (Andrews et al. loc. cit.). More recently, a $4 \mathrm{hr}-\mathrm{LC}_{50}$ for NCL miracidicidal effect as low as $0.03 \mathrm{mg} / 1$ was obtained by PB Tchounwou et al. (1991 J Environ Sci Health B26: 69-82). On the other hand, it was reported that $S$. mansoni cercariae were rapidly killed by NCL at concentrations as low as $0.1-0.2$ $\mathrm{mg} / \mathrm{l}$ (Andrews et al. loc. cit). PB Tchounwou et al. (1992 Environ Toxicol Water Qual 7: 107-117) also investigated the cercaricidal effect of NCL and found a $4 \mathrm{hr}-\mathrm{LC}_{50}$ equal to $0.04 \mathrm{mg} / \mathrm{l}$. In the present study, miracidicidal and cercaricidal effects of NCL were noted at a concentration as low as $0.05 \mathrm{mg} / \mathrm{l}$. It is of note that this concentration of NCL is well below its $24 \mathrm{hr}-\mathrm{LC}_{50}(0.16 \mathrm{mg} / \mathrm{l})$ and $24 \mathrm{hr}-\mathrm{LC}_{90}(0.31 \mathrm{mg} / \mathrm{l})$ for adult B. glabrata snails (EC Oliveira-Filho 1995 Estudo Ecotoxicológico do Látex Moluscicida da Coroa de Cristo, Euphorbia milii var hislopii, MSc Thesis, Fundação Oswaldo Cruz, Rio de Janeiro, 157 pp.). The data presented in this paper thus suggest that $S$. mansoni free living stages are killed by NCL at concentrations which are not lethal to their intermediate host snails. However, results also showed that, at such a low concentration of NCL $(0.05 \mathrm{mg} / \mathrm{l})$, a rela-

\section{TABLE I}

Mortality (cummulative) of Schistosoma mansoni miracidia exposed to Euphorbia milii lyophilized latex and niclosamide for 2, 3 and $4 \mathrm{hr}$. Data are shown as percentage $(\%)$ of dead miracidia. $(\mathrm{N}=30$ miracidia per concentration)

\begin{tabular}{lccc}
\hline $\begin{array}{l}\text { Concentration } \\
(\mathrm{mg} / \mathrm{l})\end{array}$ & \multicolumn{3}{c}{ Duration of exposure (hr) } \\
\cline { 2 - 4 } & 2 & 3 & 4 \\
\hline
\end{tabular}

\section{E. milii latex}

\begin{tabular}{llll}
0 & 10 & 20 & 23 \\
10 & $33^{*}$ & $63^{*}$ & $77^{*}$ \\
25 & $53^{*}$ & $63^{*}$ & $67^{*}$ \\
50 & $47^{*}$ & $57^{*}$ & $73^{*}$ \\
100 & $43^{*}$ & $57^{*}$ & $80^{*}$ \\
Niclosamide & & & \\
0.05 & $87^{*}$ & $90^{*}$ & $100^{*}$ \\
\hline
\end{tabular}

Statistical comparisons were made by the chi-square test. Mortality indices $(\%)$ significantly different $(P<0.05)$ from those found for dechlorinated-water controls $(0 \mathrm{mg} / \mathrm{l})$ are indicated by an asterisk (*). tively long exposure period is necessary to induce cercarial deaths. While exposure of cercariae to NCL $(0.05 \mathrm{mg} / \mathrm{l})$ for $4 \mathrm{hr}$ resulted in $68.8 \%$ mortality rate in one experiment (Table II), exposure for just $2 \mathrm{hr}$ was ineffective in increasing cercarial mortality in the infectivity test (Figure). Neither the cercarial survival, nor the proportion of cercariae that penetrated the mouse skin was affected after a $2 \mathrm{hr}$ exposure to NCL $(0.05 \mathrm{mg} / \mathrm{l})$. On the other hand, none of these penetrating NCL-treated cercariae developed into adult worm in infected mice. These findings suggest that NCL does not just kill cercariae, at higher concentrations and longer exposures, but also render most of the surviving ones incapable of developing into adult worms in the final host. Similar results were also obtained by Tchounwou et al. (1992 loc. cit.) with a different sample of $S$. mansoni. These authors noted that the percentages of worms recovered from NHI mice infected with cercariae pre-exposed to dechlorinated water alone, and NCL $0.02 \mathrm{mg} / \mathrm{l}$ and $0.04 \mathrm{mg} / \mathrm{l}$, were $61.6 \%, 16.3 \%$ and $1.5 \%$, respectively. It should be pointed out that infectivity of their S. mansoni sample (untreated controls: $61.6 \%$,) was higher than that observed with the $\mathrm{BH}$ strain used in our experiment (untreated controls: 23\%). On the other hand, RMF De-Oliveira (1996 Características Parasitológicas e Perfil Isoenzimático de Amostras de Schistosoma mansoni Sambon 1907, MSc Thesis, Fundação Oswaldo Cruz, Rio de Janeiro, 112 pp.) obtained a similar infectivity rate $(25.5 \%)$ with the same BH strain. As demonstrated by RMF De-Oliveira, infectivity in mice of $S$. mansoni cercariae varies with the origin of the worm sample used.

\section{TABLE II}

Mortality of Schistosoma mansoni cercariae exposed to aqueous solutions of Euphorbia milii lyophilized latex and niclosamide for $4 \mathrm{hr}$

\begin{tabular}{|c|c|}
\hline & S. mansoni cercariae \\
\hline $\mathrm{g} / \mathrm{l}$ & Tested $(\mathrm{Nr})$ Dead $(\mathrm{Nr})$ Dead/tested $(\%)$ \\
\hline
\end{tabular}

\section{E. milii latex}

$\begin{array}{lllc}0 & 602 & 28 & 4.6 \\ 10 & 606 & 66 & 10.9^{*} \\ 25 & 602 & 53 & 8.8^{*} \\ 50 & 602 & 33 & 5.5 \\ 100 & 605 & 87 & 14.4^{*} \\ \text { Niclosamide } & & & \\ 0.05 & 606 & 417 & 68.8^{*}\end{array}$

Statistical comparisons were made by the chi-square test. Mortality indices $(\%)$ significantly different $(P<0.05)$ from those found for dechlorinated-water controls $(0 \mathrm{mg} / \mathrm{l})$ are indicated by an asterisk $(*)$. 


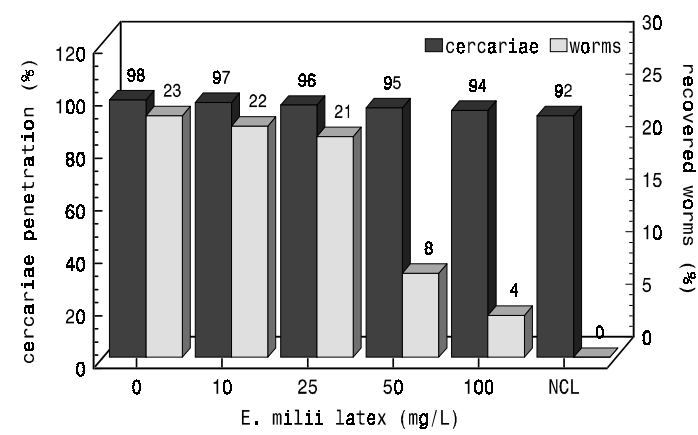

Effects of Euphorbia milii latex and niclosamide (NCL) on the infectivity of Schistosoma mansoni cercariae. Freshly shed cercariae (BH strain) were exposed to dechlorinated water $(0 \mathrm{mg} /$ 1), lyophilized latex $(10,25,50$ and $100 \mathrm{mg} / \mathrm{l})$ or NCL $(0.05$ $\mathrm{mg} / \mathrm{l}$ ) for $2 \mathrm{hr}$. Mice were next exposed to cercariae for $30 \mathrm{~min}$ by the tail immersion technique. On the left (dark columns): \% of cercariae that penetrated the mouse skin. On the right (gray columns): $\%$ of worms recovered eight weeks later. Data were analyzed by the chi-square test. $\%$ of recovered worms was significantly different $(P<0.05)$ from controls $(0 \mathrm{mg} / \mathrm{l})$ at the two highest concentrations of E. milii latex (50 and $100 \mathrm{mg} / \mathrm{l}$ ) and NCL. No other statistically significant difference was found.

E. milii latex (10-100 mg/l) did not show any inhibitory effect on $S$. mansoni eggs hatching. Furthermore, latex proved to be only slightly toxic to miracidia (Table I) and cercariae (Table II). Miracidicidal and cercaricidal effects of latex were tested at concentrations ranging from 10 to 100 $\mathrm{mg} / \mathrm{l}$, i.e. concentrations which are 15 to 150 times higher than the $24 \mathrm{hr}-\mathrm{LC}_{90}(0.67 \mathrm{mg} / \mathrm{l})$ for adult $B$. glabrata snails (Oliveira-Filho loc. cit.). Miracidium mortality was found to be somewhat higher in latex solutions than in untreated controls, but no concentration-effect relationship was observed at any exposure time. Moreover, even at the highest concentration tested $(100 \mathrm{mg} / \mathrm{l})$, latex was ineffective in achieving a $100 \%$ mortality rate during a $4 \mathrm{hr}$ exposure period (Table I). Similar re- sults were obtained with regard to cercarial lethality. In most instances cercarial mortality was slightly higher in latex solutions than in controls, but again no concentration-effect relationship was found (Table II). Even at the highest concentration of latex tested $(100 \mathrm{mg} / \mathrm{l})$ mortality rate was as low as $14.4 \%$, a lethal effect well below that obtained with $0.05 \mathrm{mg} / \mathrm{l}$ of NCL $(68.8 \%)$. Contrasting with the absence of consistent lethal effects of latex on swimming cercariae, a concentration-dependent effect was observed in the cercariae infectivity test (Figure). Neither cercarial survival, nor the percentage of cercariae that succeeded in penetrating the mice skin was reduced by latex $(10-100 \mathrm{mg} / \mathrm{l}$, for $2 \mathrm{hr}$ ). Nonetheless, the percentage of recovered worms was substantially reduced in mice infected with cercariae exposed to 50 and $100 \mathrm{mg} / \mathrm{l}$ of latex. This result suggested that $E$. milii latex - at least at the two highest concentrations tested - was toxic to $S$. mansoni cercariae rendering them incapable of developing into adult worms in the final host. From these observations one has to conclude that latex is slightly toxic to S.mansoni free living stages at concentrations much higher than those which are sufficient to kill their intermediate host snails. Thus, in contrast to NCL, E. milii molluscicidal latex does not present the additional advantage of also affecting the viability of schistosoma miracidia and cercariae.

In conclusion, E. milii latex had no effect on $S$. mansoni eggs and was slightly toxic to miracidia and cercariae. NCL, on the other hand, was effective in killing miracidia and cercariae at a concentration which is not lethal to their intermediate host snails. These findings seems to support the view that, in comparison with the reference molluscicide NCL, E. milii latex has a narrower spectrum of biocidal actions.

Aknowledgments: to the staff of the Department of Malacology, Oswaldo Cruz Institute, Fiocruz, for providing the parasite strain. 
238 Effects of E. milii Latex on S. mansoni - Rosangela R De-Carvalho et al. 